\title{
Environmental Damage Caused by Wastewater Discharge into the Lake Manzala in Egypt
}

\author{
Ahmed Ismail ${ }^{1}$, Hiroshan Hettiarachchi ${ }^{2}$ \\ ${ }^{1}$ Department of Environmental Sciences, Faculty of Science, University of Port Said, Port Said, Egypt \\ ${ }^{2}$ Institute for Integrated Management of Material Fluxes and of Resources, United Nations University (UNU-FLORES), Dresden, Germany
}

Email address:

h.meda77@yahoo.com (A. Ismail)

To cite this article:

Ahmed Ismail, Hiroshan Hettiarachchi. Environmental Damage Caused by Wastewater Discharge into the Lake Manzala in Egypt. American Journal of Bioscience and Bioengineering. Vol. 5, No. 6, 2017, pp. 141-150. doi: 10.11648/j.bio.20170506.14

Received: November 11, 2017; Accepted: November 22, 2017; Published: December 25, 2017

\begin{abstract}
Lake Manzala is a brackish lake in northeastern Egypt on the Nile Delta. It is the largest of the northern Delta lakes of Egypt. The Lake is exposed to high inputs of pollutants from industrial, domestic, and agricultural sources. Climate gases and large amounts of particulate matter, nutrients, bacteria, heavy metals, and toxic organics are transported to the Lake through the wastewater discharge. Water samples were collected and subjected to physicochemical analysis and microbiological study. Results have shown great changes in physical and chemical properties of water including: temperature $\left(13.5^{\circ} \mathrm{C}\right.$ in winter $-32^{\circ} \mathrm{C}$ in summer), $\mathrm{pH}(7.8-9.2)$, dissolved oxygen $\left(2.5-12.8 \mathrm{mgl}^{-1}\right)$, total dissolved solids $\left(1033-43406 \mathrm{mgl}^{-1}\right)$, total suspended solids $\left(120-387 \mathrm{mgl}^{-1}\right)$, ammonia $\left(2.5-32.3 \mathrm{mgl}^{-1}\right)$, nitrite $\left(0-0.076 \mathrm{mgl}^{-1}\right)$, nitrate $(0.01-$ $\left.7.88 \mathrm{mgl}^{-1}\right)$, phosphate $\left(0.26-2.37 \mathrm{mgl}^{-1}\right), \mathrm{Fe}\left(0.01-0.63 \mathrm{mgl}^{-1}\right), \mathrm{Zn}\left(0-0.35 \mathrm{mgl}^{-1}\right), \mathrm{Cu}\left(0.01-0.91 \mathrm{mgl}^{-1}\right), \mathrm{Cn}(0.002-0.029$ $\left.\mathrm{mgl}^{-1}\right)$ and $\mathrm{Ni}\left(0-0.002 \mathrm{mgl}^{-1}\right)$. Results, also, showed a quit great density of total viable bacterial count and indicator organisms including total Coli forms, fecal coli forms, Aeromonas spp., Staphylococcus spp. and Vibrio spp. It is concluded that water in Lake Manzala is highly damaged and the phenomena need more attention in order to reduce the pollution load that reaches the Mediterranean Sea.
\end{abstract}

Keywords: Lake Manzala, Wastewater, Water Quality, Heavy Metals, Bacterial Indicators

\section{Introduction}

\subsection{Lake Manzala}

Lake Manzalais located on the northeastern edge of the Nile Delta in Egypt, close to Port Said between $31^{\circ} 00-31^{\circ}$ $35^{\backslash} \mathrm{N}$ latitude and $31^{\circ} 45^{\backslash}-32^{\circ} 15^{\backslash} \mathrm{E}$ longitudes with an area of approximately $1000 \mathrm{~km}^{2}$ (Figure 1). Lake Manzala is a highly dynamic aquatic system that has undergone considerable physical, chemical and biological changes. The lake has been gradually transformed from a largely marine or estuarine environment to a eutrophic nearly fresh water system which can have significant negative ecological, health, social and economic impacts on human. This was a result of different aspects of human impacts mainly wastewater discharge into the lakeas well as different aspects of human impacts of which closing and/or opening of straits, continuous drying processes for human settlement and silting of the lake.

\subsection{Wastewater Discharge into Lake Manzala}

A large number of islands are presented in Lake Manzala. El-Bayomy [1] stated that the number of islands reaches 304 accounting for $23 \%$ of the total lake's area. Lake Manzala is connected with the Mediterranean Sea by the straits of ElGamil, Ashtoum Al-Gamil, Al-Baghdadi, El-Deiba and AlBurg at the northwest corner of the lake. The lake is in contact with the Suez Canal through a small navigating canal known as Al-Qabouti or the internal canal. These openings supply the lake with marine water and allow an exchange of water between the Lake and the Sea. This makes the northern portion of Lake to be characterized by high total dissolved solids (TDS) content is up to $43406 \mathrm{mgl}^{-1}$ (present study) due to the influence of the Mediterranean Sea. 

Lake Manzala in Egypt

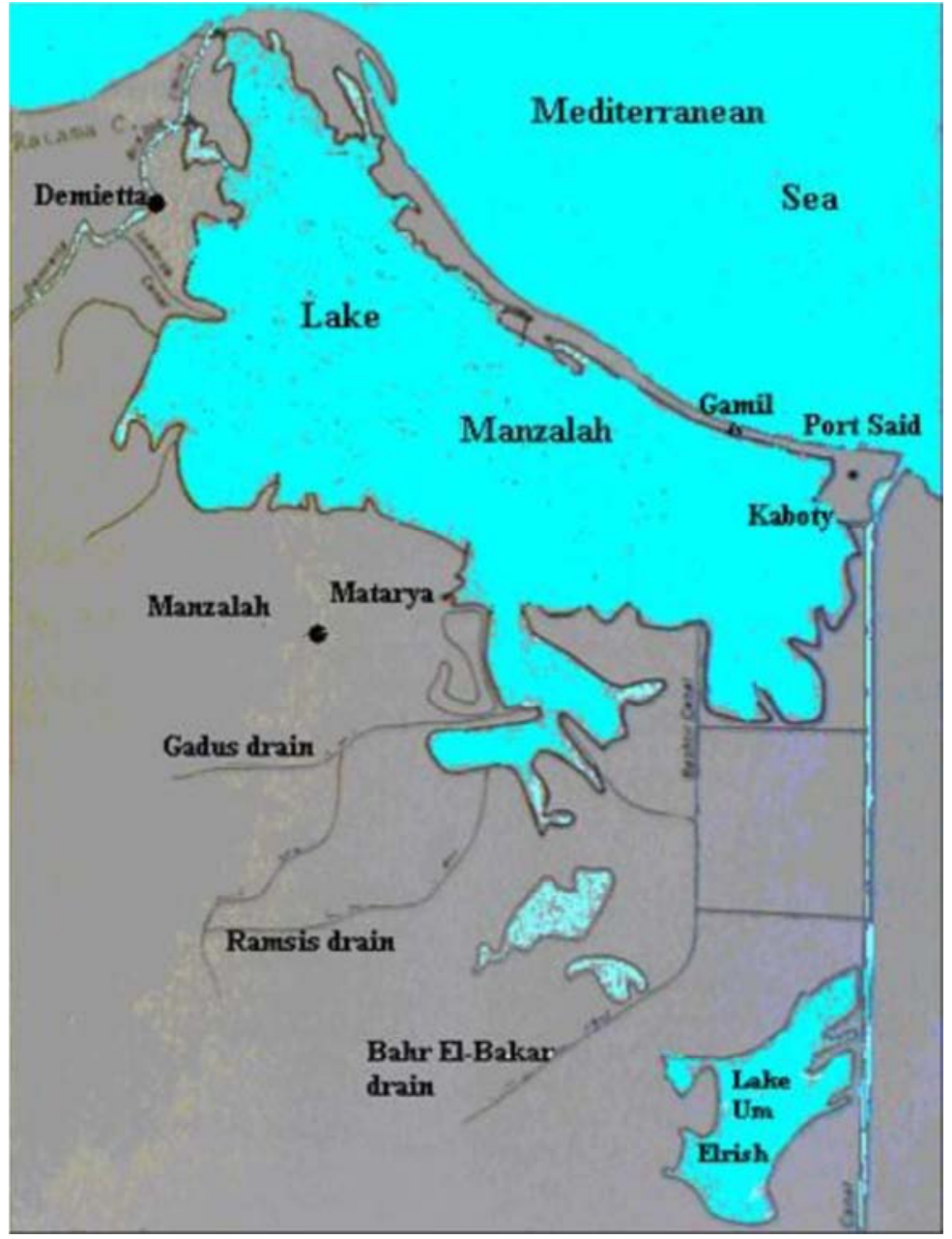

(A)

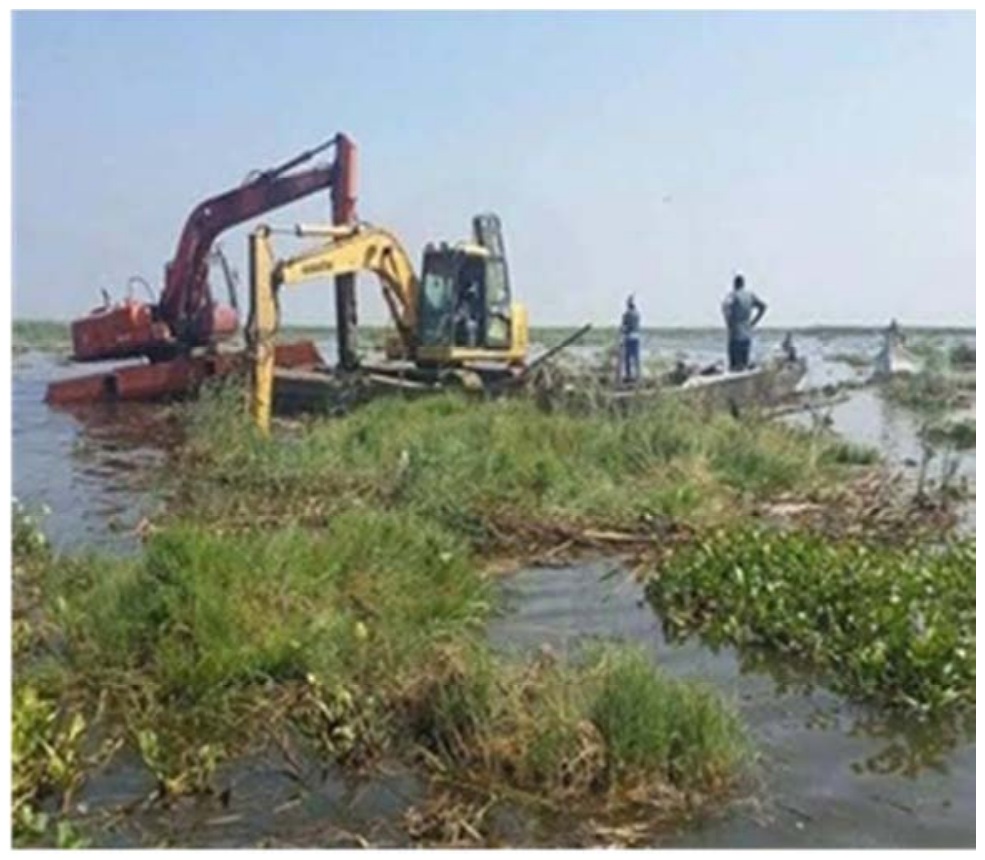

(B)

Figure 1. Lake Manzala. (A) Satellite map, (B) Remediation activity. 
The Lake is exposed to high inputs of pollutants from industrial, domestic, and agricultural sources. The western and southern coasts have many inlets by which great amounts of wastewater discharge into the lake carrying large amounts of particulate matter, nutrients, bacteria, heavy metals, and toxic organics. The Lake received about 7500 million cubic meters of untreated industrial, domestic and agricultural drainage water, discharged annually through six main drains (Table 1); Bahr El-Baqer Drain (domestic and industrial sewage), Hadous Drain, Ramsis Drain, El-Serw Drain, Matariya Drain and Faraskour Drain (agricultural wastewater). This amount of wastewater was reduced to about 4000 million cubic meters after construction of ElSalam Canal [2].

Table 1. Main drains of wastewater discharge into Lake Manzala.

\begin{tabular}{llll}
\hline Drains & Type of wastewater & Serving area (feddans *) & Total wastewater flow in the Lake (\%) \\
\hline Bahr El-Baqer Drain & Mainly domestic and industrial & 536000 & 25 \\
Hadous Drain & Mainly agricultural & 790000 & 49 \\
Ramsis Drain & Mainly agricultural & NA & 4 \\
El-Serw Drain & Mainly agricultural & 68700 & 13 \\
Faraskour Drain & Mainly agricultural & 20000 & 4 \\
Matariya Drain & Mainly agricultural & NA & 2 \\
\hline
\end{tabular}

*Approximately 4,200.833 square meters (about 1.038 acres).

The poor quality of the north flowing drainage wastewaters is a major environmental and economic concern in Egypt. Much of the heavily polluted drain water crossing the Nile Delta enters Lake Manzala before flowing into the Mediterranean Sea. Untreated and poorly treated wastewater degrading the Lake and sending pollution downstream into the Mediterranean Sea which is in violation of international agreements signed by Egypt. Pollution originates in urban centers such as Cairo and also along the lengths of the drains. Domestic and industrial wastewaters are transported to Lake Manzala by the Bahr El Baqar drain over a distance of 170 $\mathrm{km}$. The drain is heavily polluted and anoxic over its entire length. Climate gases and large amounts of particulate matter, nutrients, bacteria, heavy metals, and toxic organics are transported to the Lake via the drain. Santos [4] and Prasanna [5] stated that the most anthropogenic sources of metals in water are industrial, petroleum contamination and sewage disposal. The agricultural drainage water containing pesticides and fertilizers and effluents of industrial activities and runoffs in addition to sewage effluents supply the water bodies and sediment with huge quantities of inorganic anions and heavy metals [6]. In the Egyptian irrigation system, the main source of $\mathrm{Cu}$ and $\mathrm{Pb}$ are industrial wastes as well as algaecides, while that of $\mathrm{Cd}$ is the phosphatic fertilizers used in crop farms [7].

Before the big load of wastewater discharge into the Lake Manzala, its salinity was higher and the nutrient and toxic loads were much lower. At the present time the Lake suffers from many environmental issues caused by environmental and contaminant stress. The most important local problem is the quality of water in the area. Contaminated drain water is used by local residents for washing clothes, dishes and vegetables. The absence drinking water network in most of The Lake area have human to import water from nearby Port Said and Mataryia cities. The transportation process is mostly made water not suitable for human use. Contaminated drinking water is responsible for enteric diseases such as gastritis, infective hepatitis, amoebic dysentery, and other water born parasitic infections. Moreover Tilapia fish catches from the southeastern basin area near the Bahr El Baqar drain inlet show a high frequency $(85 \%)$ of organ malformation and discoloration as a result of poor water quality. As the anoxic wastewater is discharged into Lake Manzala, reduced iron is oxidized and precipitated as hydroxide in a zone of gray water between the black drain water and the green Lake water. The oxidized iron precipitates on fish gills, causing tissue damage and mortality. Among the Port Said inhabitants, Lake Manzala fish have a reputation for being chemically and microbiologically contaminated and, thus, unhealthy to eat. The public are afraid to eat fish from a Lake that once provided 30 percent of all Egypt's fish.

Lake Manzala suffered from a high level of eutrophication, due to the heavy load of nutrients, especially phosphorus and nitrogen compounds due to agricultural runoff, sewage and drains discharges [8]. The Lake is highly eutrophic with both macrophytes and planktonic algae contributing to extensive carbon fixation. A large proportion of the primary production occurs in macrophytes which constitute a "blind path" in the aquatic food web. Only the hardiest organisms can tolerate Lake Manzala near the entrance of the Bahr El Baqar drain and substantial reduction of biodiversity was reported over the last few decades in both fish and bird species.

\subsection{Physical, Chemical and Bacterial Pollutants}

Lake Manzala receives an annual 7.2 billion cubic metres of annual water inflow; 3.9 per cent of which from sewage, 96 per cent from agricultural drainage and 0.1 per cent from industrial drainage. The original capacity of the lake is 0.43 billion cubic meters, which is means that Lake Manzala receives 16 times its original size in drainage water inflow. This makes the water current of the lake move in a single direction from the lake into the sea all year long without allowing any water flow from the sea into the lake, except during the winter storms. This has a negative impact on the lake's hydrological cycle, which works to renew its waters, adjust salinity levels and reduce pollutants.

Physical, chemical and microbial characteristics of water are used by the Egyptian Environmental Affairs Agency 
(EEAA) to determine the healthy status of water. These parameters are: water temperature, electric conductivity (EC), total suspended solids (TSS), $\mathrm{pH}$, dissolved oxygen (DO), biological oxygen demand (BOD), chemical oxygen demand (COD), total nitrogen (TN), toxic heavy metals, total viable count, total coli and faecal coli forms.

Abd El-Monsef [9] stated that The comparison between the measurement of $\mathrm{As}, \mathrm{Se}, \mathrm{Sn}$ and $\mathrm{Sb}$ data and the average earth's crust according to McLennan [10] suggests that the average concentrations of $\mathrm{As}, \mathrm{Se}, \mathrm{Sn}$ and $\mathrm{Sb}$ in the Lake Manzala sediments (12, 4 and $46 \mathrm{ppm}$ and none detected for antimony) are about 8,80 and 9 fold the average earth's crust, respectively, while antimony content is depleted. Comparing with the agency for toxic substances and disease registry, which setup the sediment quality guidelines in the form of level of probable effects, the studied sediments seem to be polluted at high levels.

The use of bacteria as indicators of the sanitary quality of water probably dates back to when Von Fritsch (1880-1939) who described Klebsiella pneumoniae and $K$. rhinoscleromatis as micro-organisms characteristically found in human faeces [11]. The major groups of bacterial indicators are: Coliforms; Thermotolerant Coliforms, also known as faecal Coliforms due to their role as faecal indicators; Escherichia coli (E. coli. Most appropriate group of Coliforms to indicate faecal pollution from warm-blooded animals; faecal streptococci (FS); Enterococci and Sulphitereducing Clostridia (SRC).

The present work aims to study the physical, chemical, and microbial pollution and to evaluate damage caused by wastewater discharge into Lake Manzala.

\section{Materials and Methods}

\subsection{Sampling Methods}

Two sampling sites namely Al-Gamil (at the north part where the lake is connected with the Mediterranean Sea by the straits) and El-Bashtier (at the south part where the lake is received about 7500 million cubic meters of untreated industrial, domestic and agricultural drainage water from Bahr El-Baqer Drain and density human activities were selected (Figure 2).

Water samples were collected during January (wet season) and July (dry season), in $2 \mathrm{~L}$ clean sterile glass bottle $10 \mathrm{Cm}$ blew water surface. Samples were transported to the laboratory in ice bags for direct examination. Temperature, $\mathrm{PH}$, and DO were determined directly in the field and the other physical, chemical and bacteriological analyses were done in the laboratory.

\subsection{Physical and Chemical Analyses}

Total dissolved solids, total suspended solids, ammonia, nitrite, nitrate; phosphate and heavy metals analyses were done according to American Public Health Association Standard Methods $22^{\text {th }}$ ed., [12]. Heavy metals content in water samples were determined by acid digestion. Fifteen $\mathrm{ml}$ of $\mathrm{HNO}_{3}$ were added to $250 \mathrm{ml}$ of each sample then heated until $25 \mathrm{ml}$. The solution was transferred into $50 \mathrm{ml}$ volumetric flask and made up to the mark with distilled water. Then, heavy metals were detected by Atomic Absorption Spectrophotometer (AAS), flame type.

\subsection{Bacterial Pollutants}

Water samples were directly diluted with $0.8 \%$ saline distilled water for bacterial counting using the dilution method and pouring plate method. A total viable bacterium was determined using nutrient agar medium while total coli forms and faecal coli forms were estimated using Endo agar medium [12]. Aeromonas spp., Staphylococcus spp. and Vibrio spp were determined using Aeromonas differential medium, salt mannitol agar and thiosulphate citrate bile salts sucrose agar respectively [12]. The significance of relationships between the bacterial count and water characteristics of Lake Manzala was tested using Correlation analysis [13]. The correlation coefficient (r) and the probability (p) were used.

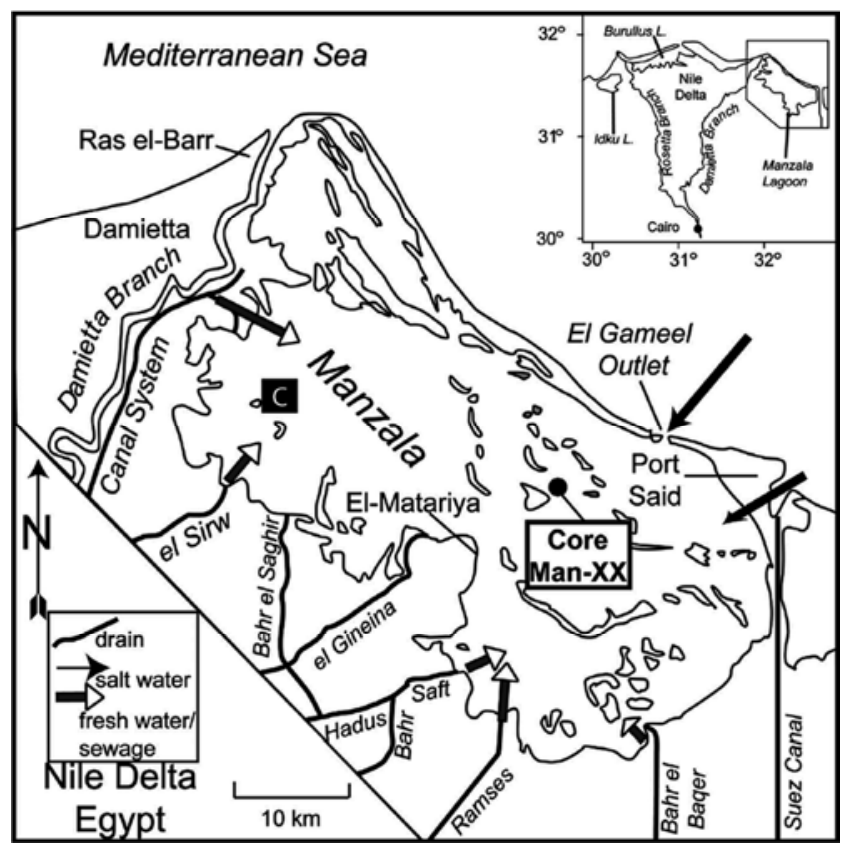

Figure 2. Main drains and Sites of water sampling, Google Maps.

\section{Results and Discussion}

\subsection{Physical and Chemical Analyses}

The results in (table 2) showed that there was no great difference between the two sampling sites in water temperatures within the same season. It ranged between 13.5 $-14^{\circ} \mathrm{C}$ in winter and $31.5-32^{\circ} \mathrm{C}$ in summer. There was insignificant difference between temperatures in the studied sites (Figure 3A). The temperature is basically important for its effects on the chemistry and biological activities of organisms in water. It is also known to influence in the determination of other factors like $\mathrm{pH}$, conductivity, and dissolved oxygen. 
Table 2. Physical and chemical parameters of water samples collected from LakeManzala.

\begin{tabular}{|c|c|c|c|c|c|}
\hline \multirow[b]{2}{*}{ Parameter } & \multicolumn{2}{|l|}{ Al-Gamil } & \multicolumn{2}{|c|}{ El- Bashtier } & \multirow{2}{*}{ Permissible Limits" } \\
\hline & Winter & Summer & Winter & Summer & \\
\hline Temperature ${ }^{\circ} \mathrm{C}$ & 14 & 32 & 13.5 & 31.5 & $<35$ \\
\hline $\mathrm{pH}$ & 9.2 & 8.9 & 8.0 & 7.8 & $6.0-9.0$ \\
\hline $\mathrm{DO}\left(\mathrm{mgl}^{-1}\right)$ & 12.8 & 10.2 & 3.4 & 2.5 & $>4$ \\
\hline $\operatorname{TDS}\left(\mathrm{mgl}^{-1}\right)$ & 43406 & 40813 & 1033 & 1485 & $<2000$ \\
\hline $\mathrm{TSS}\left(\mathrm{mgl}^{-1}\right)$ & 387 & 342 & 120 & 120 & $<60$ \\
\hline Ammonia $\left(\mathrm{mgl}^{-1}\right)$ & 2.8 & 2.5 & 32.3 & 29.18 & $<0.5$ \\
\hline Nitrite $\left(\mathrm{mgl}^{-1}\right)$ & 0.06 & 0.00 & 0.76 & 0.68 & $<0.3$ \\
\hline Nitrate $\left(\mathrm{mgl}^{-1}\right)$ & 0.07 & 0.01 & 7.88 & 7.19 & $11.3-45$ \\
\hline Phosphate $\left(\mathrm{mgl}^{-1}\right)$ & 0.26 & 0.94 & 2.05 & 2.37 & 1.0 \\
\hline
\end{tabular}

* Permissible Limits of Egypt legislation of the national law 48/1982.

Also, there was insignificant differences between the two sampling sites and seasons in water $\mathrm{pH}$. The $\mathrm{pH}$ values were ranged from 7.8 in El-Bashtier site to 9.2 in Al-Gamil site (Figure 3B). The high $\mathrm{pH}$ value at Al-Gamil area is due to the direct connection between the lake and the Mediterranean sea which allow water to move in and out Lake Manzala. The lower $\mathrm{pH}$ value 7.8 recorded in El-Bashtier (near the drains inputs) may due to the fermentation of the organic matter and liberation of hydrogen sulphide and methane gases and effluent fresh water drains. When organic matter in drains water breaks down, it consumes oxygen and gives off $\mathrm{CO}_{2}$ making the lake more acidic. This result comes in agreement with those obtained by Fathi [14] and Ahmed [15] who reported that the change in $\mathrm{pH}$ value of Lake Manzala was always in the alkaline side and ranged between 7.7 to 9.0.

Results also showed that there was significant difference between the dissolved oxygen in the studied sites. The minimum DO value $\left(2.5 \mathrm{mgl}^{-1}\right)$ was recorded in water sample collected from El-Bashtier site during summer while the highest value $\left(12.8 \mathrm{mgl}^{-1}\right)$ was reported in Al-Gamil site during winter (Figure 3C). The concentration of dissolved oxygen decreased from its highest value $\left(12.8 \mathrm{mgl}^{-1}\right)$ at the north part (Al-Gamil) in winter to its lowest value $\left(2.5 \mathrm{mgl}^{-1}\right)$ at the south part (El-Bashtier) of the lake during summer. The highest value $\left(12.8 \mathrm{mgl}^{-1}\right)$ may due to decreasing of temperature and to the prevailing winds which permit to increase the solubility of atmospheric oxygen [16]. This observation is noteworthy, because the dissolved oxygen concentration would more typically increase as the water temperature decreases. The fact that the opposite phenomenon is observed suggests that something else, possibly the high microbial communities, the dominant effect of drainage effluents on this location and less anthropogenic activities, are acting to decrease dissolved oxygenthe dissolved oxygen concentration fell below the minimum acceptable value to support aerobic life $\left(4 \mathrm{mgl}^{-1}\right)$ at the south part (El-Bashtier) of the lake. Similar result was reported by Bruner [17]. Dissolved oxygen is needed by fish and other aquatic organisms for their respiration and therewith an important ecological parameter. Low oxygen contents as such not directly hamper uses like production of drinking water or recreation, but can indicate pollution stresses and/or eutrophication phenomena that as such may negatively affect these functions [18].

The total dissolved solids (TDS) values showed a significant difference between the sampling sites. The minimum TDS value $\left(1033 \mathrm{mgl}^{-1}\right)$ was recorded in water sample collected from El-Bashtier site during winter while the highest value (43406 $\mathrm{mgl}^{-1}$ ) was reported in Al-Gamil site during winter (Figure 3D). In this respect El-Gawady [19] and Shakweer [20] reported that Lake Manzala can be divided into two main regions according to its salinities; the southern region of the lake which characterized by lower values of salinities and high concentration of nutrients and heavy metals as consequence of its receive high volumes of low salinity drainage water through different drains and the second region at the North Eastern area of the lake, near to the lake-sea connection (El-Gamil), which characterized by high salinity values and low nutrient concentration as a result of seawater intrusion through the outlet openings. Similar results were reported by Ramadan [21]. Major ions are present in all aquatic ecosystems just because of geogenic and other natural sources. Of course, anthropogenic activities can lead to increasing the salinity. The total suspended solids TSS was ranged from $120 \mathrm{mgl}^{-1}$ in water collected from ElBshtier site to $387 \mathrm{mgl}^{-1}$ in Al-Gamil site during winter (Figure 3E). TSS is obviously increased toward the north. Suspended particles whether of organic or mineral origin adsorb bacteria to their surfaces where the microbes find a more favorable nutritional environment than that in free water. In water with very low concentration of nutrients, most microorganisms have been shown growing on the surface of suspended particles. Moreover, inhibitory and toxic substances are neutralized by adsorption to particles of debris. Thus the suspended particles have favorable effect on the bacterial growth.

There was significant difference between the concentrations of ammonia in the studied sites. The 
minimum concentration of ammonia $\left(2.5 \mathrm{mgl}^{-1}\right)$ was recorded in water sample collected from Al-Gamil site during summer while the highest value $\left(32.3 \mathrm{mgl}^{-1}\right)$ was reported in ElBashtier site during winter (Figure $3 \mathrm{~F}$ ). The excess ammonia recorded in El-Bashtier area indicates polluted water and maximum algal growth. All proteins contain nitrogen, as do a wide variety of other biomolecules when metabolized; much of this nitrogen can end up in the form of ammonia $\left(\mathrm{NH}_{3}\right)$. Moreover, the percentage of $\mathrm{NH}_{3}$ is known to increase with temperature and $\mathrm{pH}$. The low value of DO $\left(2.5 \mathrm{mgl}^{-1}\right)$ and the receiving of about 7500 million cubic meters of untreated industrial, domestic and agricultural drainage water, discharged annually into the lake through several drains may considered as other causes of ammonia pollution.

The amounts of nitrite have shown to be varied among the two sample collecting sites. Its concentration ranged from 0.0 $\mathrm{mgl}^{-1}$ in water from Al-Gamil site during summer to 0.76 $\mathrm{mgl}^{-1}$ in El-Bashtier site during winter (Figure 3G). This result can be explained by the fact that nitrite is relatively short lived in water, because it is quickly converted to nitrate by bacteria. Because of its short lifetime, pollution with $\mathrm{NO}_{2}$ mainly is relevant for aquatic organisms.

Nitrate reported the amount of $0.01-7.88 \mathrm{mgl}^{-1}$ in water from the investigated sites. The minimum concentration of nitrate $\left(0.01 \mathrm{mgl}^{-1}\right)$ was recorded in water sample collected from Al-Gamil site during summer while the highest value $\left(7.88 \mathrm{mgl}^{-1}\right)$ was reported in El-Bashtier site during winter (Figure $3 \mathrm{H}$ ). Organic nitrogen is broken down to ammonium $\left(\mathrm{NH}_{4} / \mathrm{NH}_{3}\right)$. The high value $\left(7.88 \mathrm{mgl}^{-1}\right)$ at the south part (ElBashtier) of the lake indicates man made pollution. Man made sources of nitrate in the environment include domestic and industrial discharges, agricultural runoff where fertilizers.

There was some difference in phosphate amounts in water collected from the two sites. It ranged from $0.26 \mathrm{mgl}^{-1}$ in $\mathrm{Al}-$ Gail area during winter to $2.37 \mathrm{mgl}^{-1}$ in El-Bashtier area during summer (Figure 3I). This indicates that water in southern part of Lake Manzala is slightly eutrophicated to some extent. Whoever, nitrate and phosphate concentrations in water of the Lake still blew the permissible limits $>11.3$ $\mathrm{mgl}^{-1}$ and $1.0-2.0 \mathrm{mgl}^{-1}$ respectively [18].

Metal ions can be incorporated into food chains and concentrated in aquatic organisms to a level that affects their physiological state. Of the effective pollutants are the heavy metals which have drastic environmental impact on all organisms. Results of the present study (Table 3) have revealed that the maximum concentration of $\mathrm{Fe}$ was $(0.63$ $\mathrm{mgl}^{-1}$ ) recorded in El-Bashtier area during summer season and the minimum one $\left(0.01 \mathrm{mg}^{-1}\right)$ was reported in Al-Gamil area during winter (Figure 4A). The high concentration of $\mathrm{Fe}$ during summer than in winter may due to the elevation of temperature, which decreases the assimilation rate of $\mathrm{Fe}$ by aquatic organisms especially macrophytes [22].

Copper, $\mathrm{Cu}$ (Figure 4C) was detected in concentrations ranging from $0.01 \mathrm{mgl}^{-1}$ in water from Al-Gail site during summer to $0.85 \mathrm{mgl}^{-1}$ in El-Bashtier site during winter.
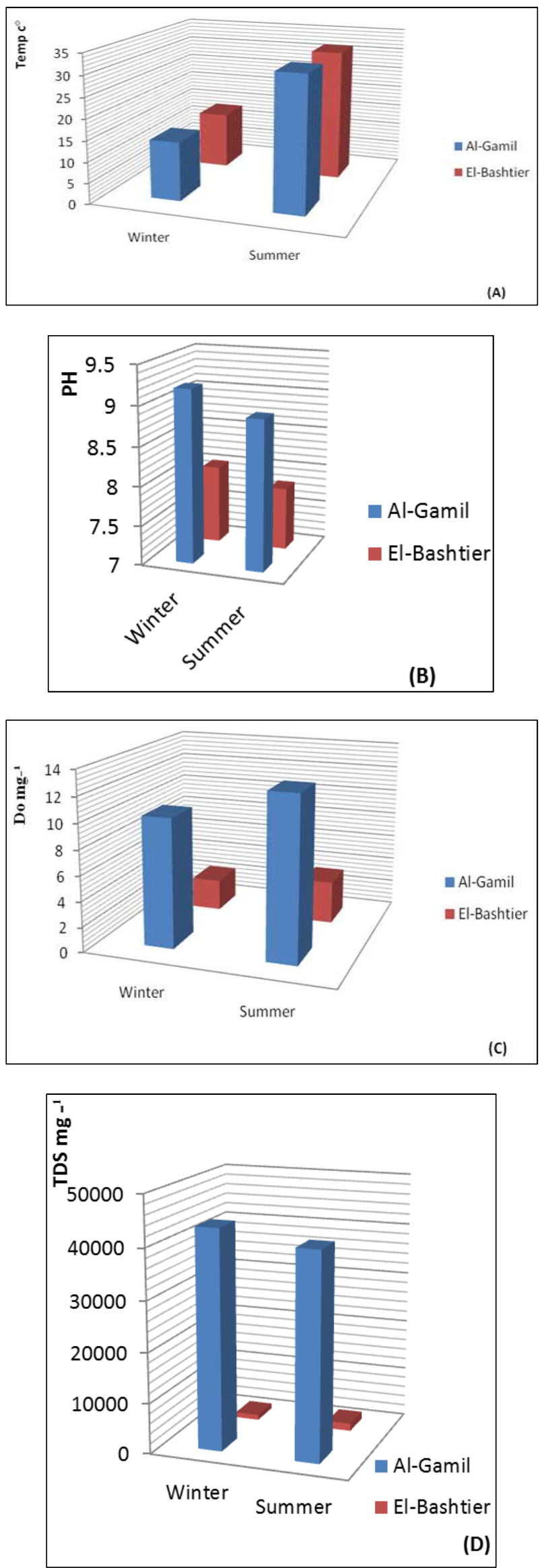

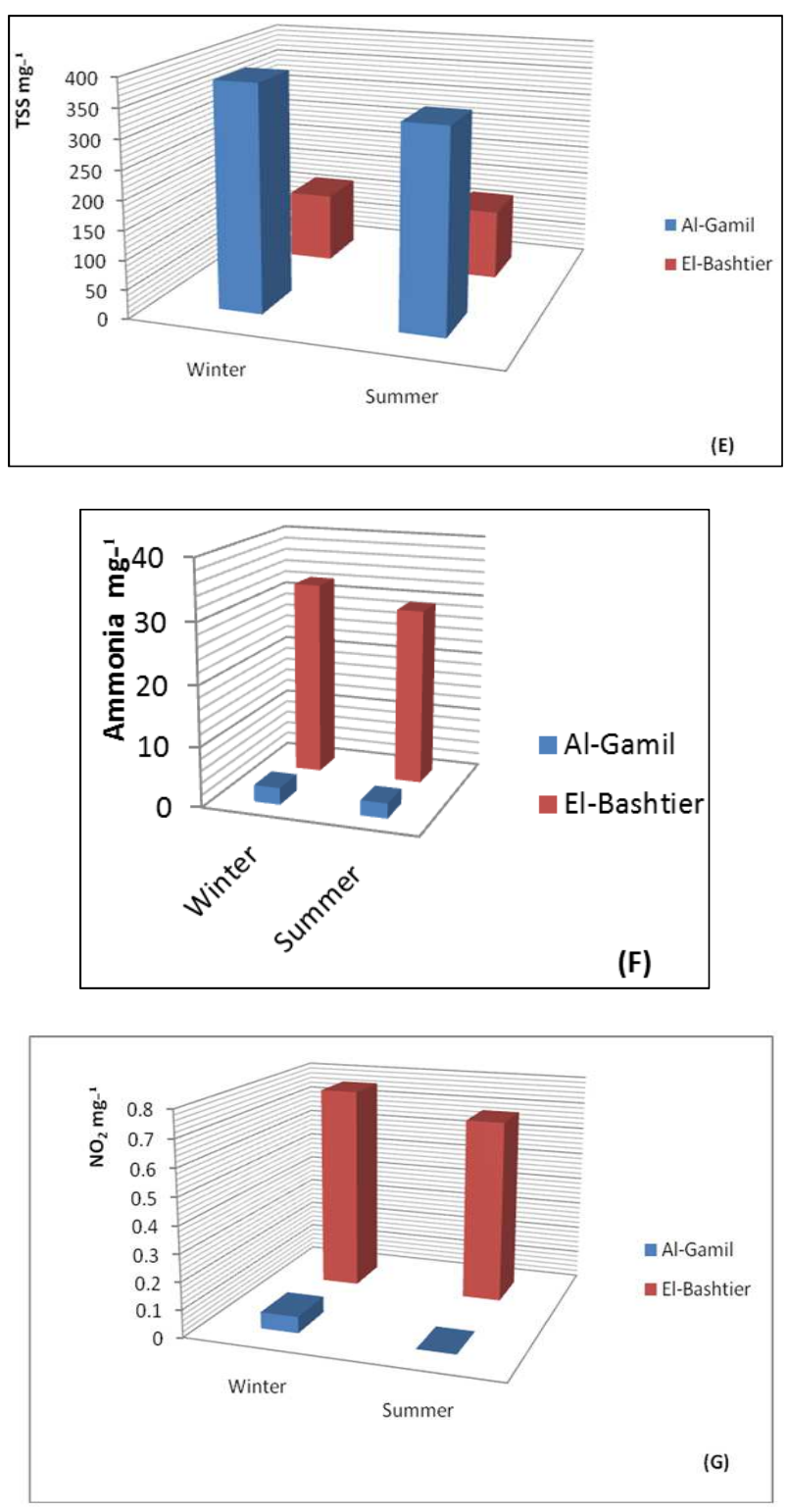
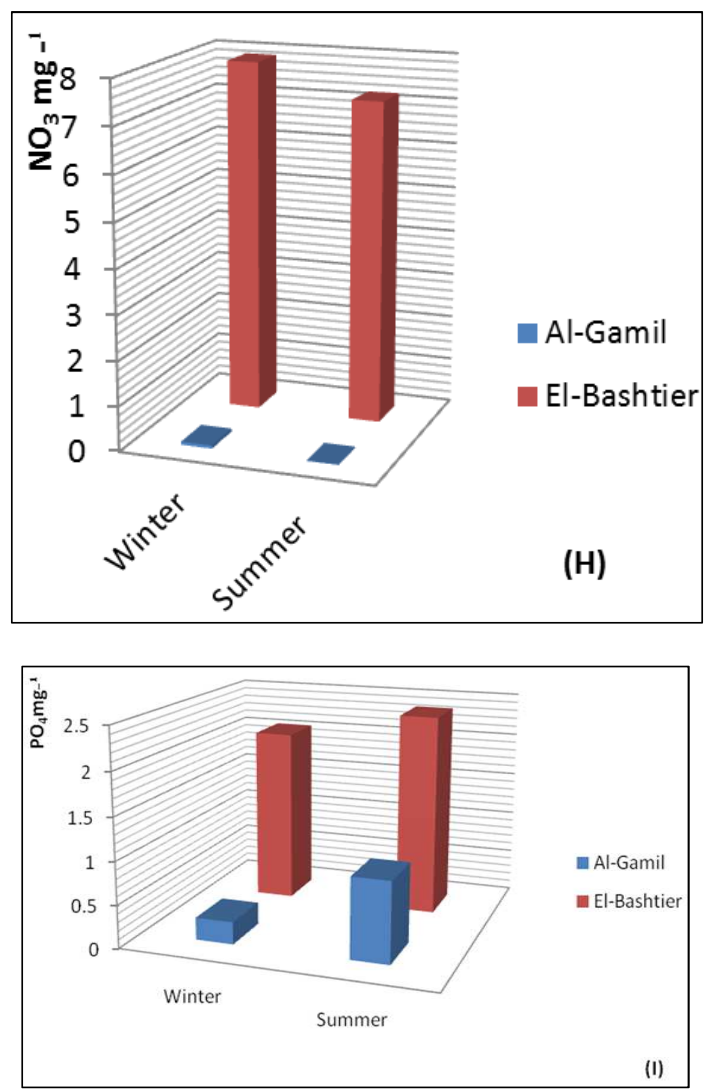

Figure 3. Physical and chemical parameters of water collected from Lake Manzala: (A) Temperature; (B) pH; (C) Dissolved oxygen, DO; (D) Total dissolved solids, TDS; (E) Total suspended solids, TSS; (F) Ammonia; (G) Nitrite, $\mathrm{NO}_{2}$; (H) Nitrate, $\mathrm{NO}_{3}$; (I) Phosphate, $\mathrm{PO}_{4}$.

For $\mathrm{Zn}$ (Figure 4B) the concentrations were from $0.0 \mathrm{mg}^{-1}$ (not detected) at Al-Gail site during winter to $0.35 \mathrm{mgl}^{-1}$ in water from El-Bashtier site during winter. The high concentration of $\mathrm{Zn}$ in water samples of Lake Manzala may be due to considerable amounts of zinc leached from protection plates of boats containing the active zinc.

Table 3. Concentration of Heavy Metals in Water Samples collected from Lake Manzala.

\begin{tabular}{llllll}
\hline \multirow{2}{*}{ Parameters } & Sites & Al-Gamil & \multicolumn{2}{l}{ El- Bashtier } & \\
\cline { 2 - 5 } & Winter & Summer & Winter & Summer \\
\hline $\mathrm{Fe}\left(\mathrm{mgl}^{-1}\right)$ & 0.01 & 0.32 & 0.56 & 0.63 & $<1.0$ \\
$\mathrm{Zn}\left(\mathrm{mgl}^{-1}\right)$ & 0.0 & 0.07 & 0.29 & 0.35 \\
$\mathrm{Cu}\left(\mathrm{mgl}^{-1}\right)$ & 0.04 & 0.01 & 0.85 & 0.41 & $<1.0$ \\
$\mathrm{CN}\left(\mathrm{mgl}^{-1}\right)$ & 0.002 & 0.003 & 0.23 & 0.29 & $<1.0$ \\
$\mathrm{Ni}\left(\mathrm{mgl}^{-1}\right)$ & 0.0 & 0.0 & 0.002 & 0.002 \\
\hline
\end{tabular}

* Permissible Limits of Egypt legislation of the national law 48/1982.

Cyanide concentration (Figure 4D) was .002 $\mathrm{mgl}^{-1}$ at AlGail sites during winter and $0.29 \mathrm{mgl}^{-1}$ in El-Bashtier site during summer. Nickel was not detected in water from AlGamil area while its concentration $0.002 \mathrm{mgl}^{-1}$ in water from El-Bashtier site (Figure 4E). Results also showed that the mean concentration of the tested metals in water of the lake was found in the following order: $\mathrm{Fe}>\mathrm{Cu}>\mathrm{Zn}>\mathrm{CN}>\mathrm{Ni}$. Concentrations of $\mathrm{Fe}, \mathrm{Cu}$ and $\mathrm{Zn}$ may be attributed to the huge amounts of raw sewage, agricultural and industrial wastewater discharged into the Lake. In this study El-
Bashtier area showed heavy metal contents higher than AlGamil area. This can explained by the fact that El-Bashtier area is nearer to drains inlet at south of Lake Manzala and demonstrated by fine sediments and high organic matter while Al-Gamil area is one sites of the Lake-sea connection which is characterized by low values of metals due to their presence far from direct drain discharge and low in organic carbon content.. More or less similar results were reported by Saeed [23]. Agu [24] stated that Iron is ubiquitous in all fresh water environments and often reaches significantly higher 
concentrations in water and sediments than other trace metals. High iron concentration in fresh waters has long been considered a problem.

\subsection{Bacterial Pollutants}

Result presented in Figure (5) showed that there is a seasonal variation in the total viable bacterial count in both investigated areas where the lowest record $\left(1.7 \times 10^{3} \mathrm{cfu} / \mathrm{ml}\right)$ was at El-Gamil site during summer and highest record $\left(1.2 \times 10^{4} \mathrm{cfu} / \mathrm{ml}\right)$ was in El-Bshtier area during summer. The total viable bacterial count was significantly correlated with temperature, total suspended solids, total dissolved salts, ammonia and nitrate $(\mathrm{r}=0.89,0.90,0.94,0.63$ and 0.85 ; $\mathrm{P}<0.05)$ respectively.

The number of the total coli forms increases from $160 \mathrm{cfu} /$ $\mathrm{ml}$ at El-Gamil site to $4150 \mathrm{cfu} / \mathrm{ml}$ at El-Bshtier area during summer. The total coli forms was significantly correlated with, total suspended solids, total dissolved salts and temperature $(\mathrm{r}=0.70,0.73$ and $0.86 ; \mathrm{P}<0.05)$ respectively. In El-Gamil $<$ outlet, the total coli forms and dissolved oxygen were significantly correlated $(\mathrm{r}=-0.90 ; \mathrm{P}<0.05)$.

The faecal coli forms recorded the highest count $(36 \times 102 \mathrm{cfu} / \mathrm{ml})$ at El-Bashtier in summer. The faecal coli forms was significantly correlated with temperature, total suspended solids and nitrate $(\mathrm{r}=0.84,0.88$ and $0.82 ; \mathrm{p}<0.05)$ respectively. In Al-Gamil area, the faecal coli form and total dissolved salts were correlated $(\mathrm{r}=0.96 ; \mathrm{p}<0.05)$.

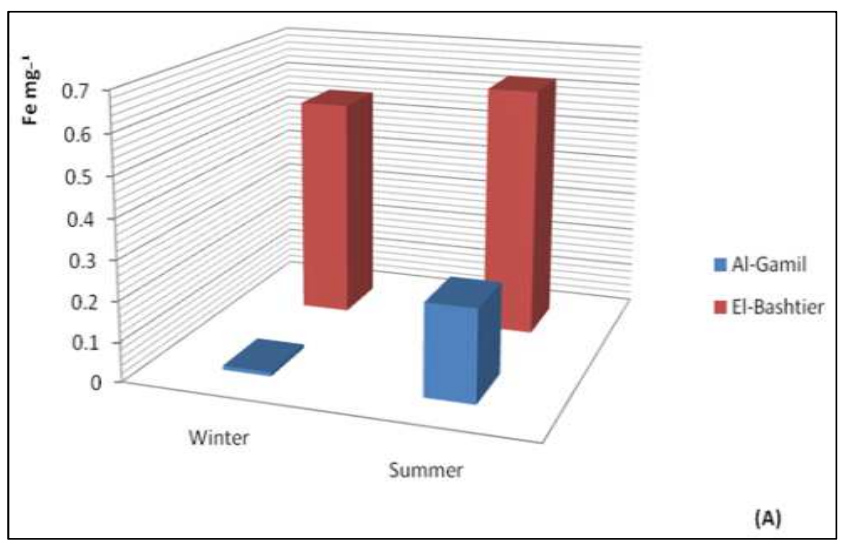

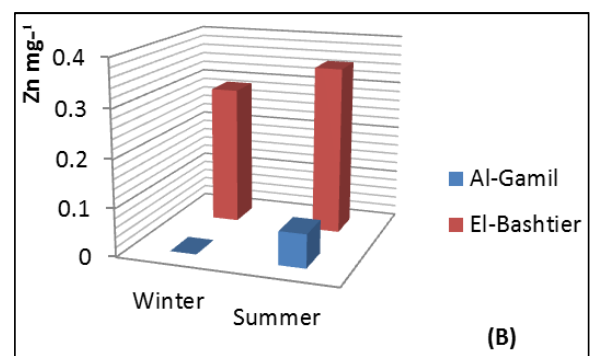
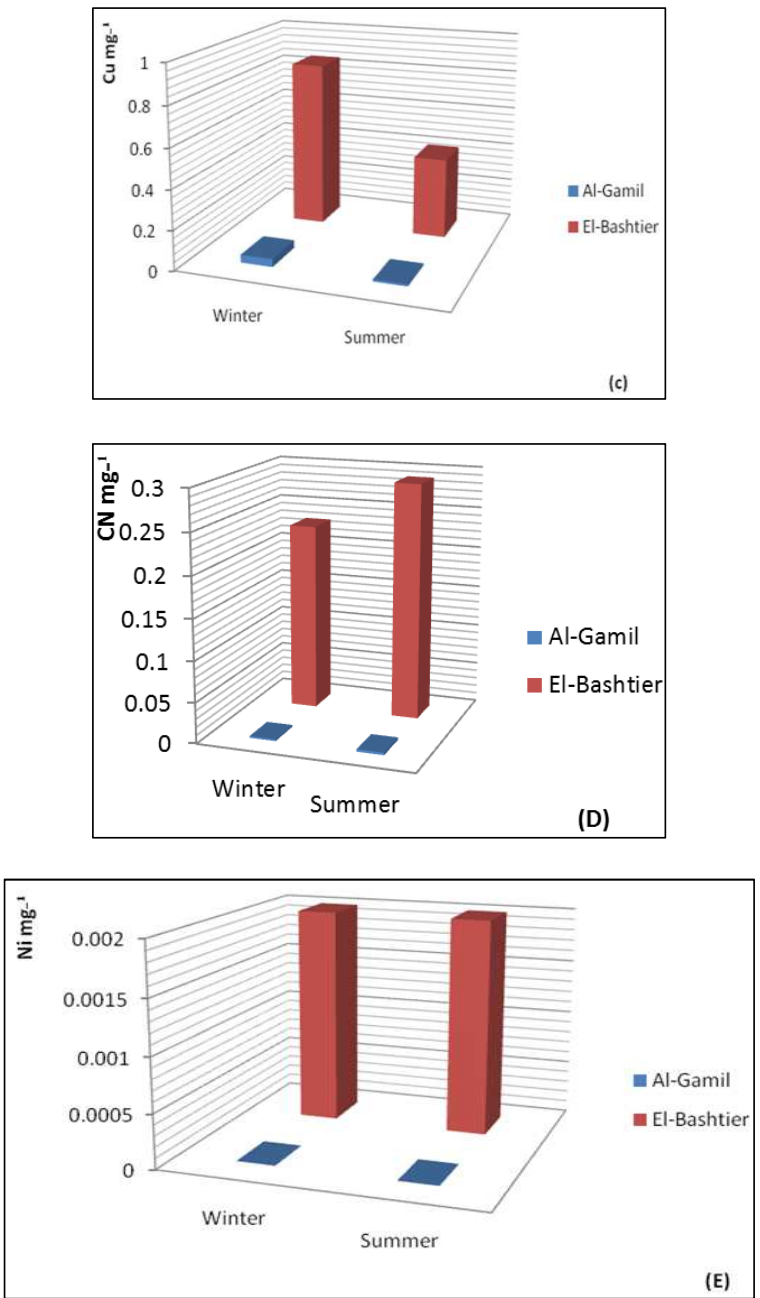

Figure 4. Concentration of heavy metals in water collected from Lake Manzala: (A) $\mathrm{Fe}$; (B) Zn; (C) $\mathrm{Cu}$; (D) $\mathrm{CN}$; (E) Ni.

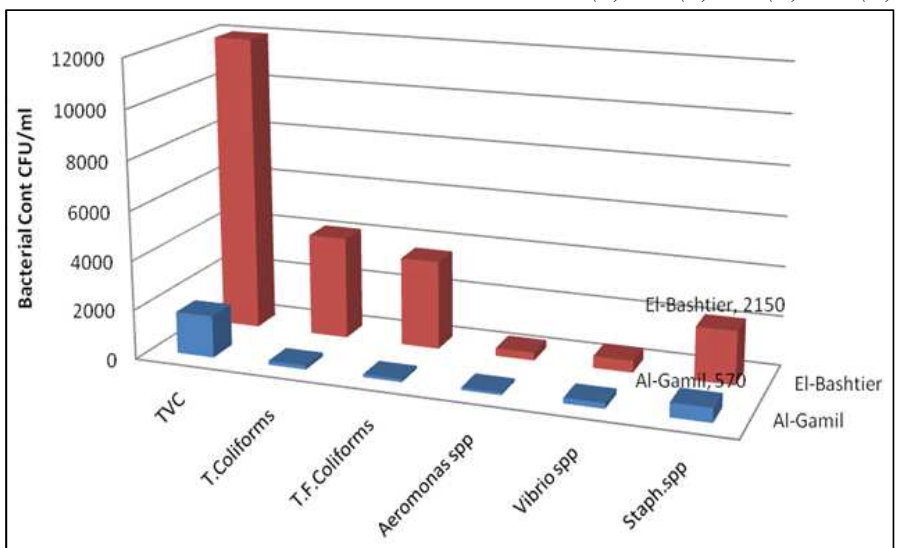

Figure 5. Bacterial pollution indicatoras a result of wastewater discharge into the Lake Manzala. 
The number of the Aeromonas spp. was generally higher in summer than the other seasons in the both studied sites. It was ranged 105-320 cfu/ml. Aeromonas spp. and ph, ammonia, nitrate and dissolved oxygen were significantly correlated $(\mathrm{r}=0.84,0.95,0.93$ and $0.97 ; \mathrm{p}<0.05)$ respectively at Al-Bashtier area. On the other hand, Aeromonas spp. and total dissolved salts were correlated $(\mathrm{r}=0.95 ; \mathrm{p}<0.05)$ at El-Gamil area.

There is a remarkable variation of the number of staphylococcus spp. in both sites where the lowest record $(570 \mathrm{cfu} / \mathrm{ml})$ at Al-Gamil and the highest count $(2150 \mathrm{cfu} / \mathrm{ml})$ at El-Bashtier site in summer staphylococcus spp. was strongly correlated with temperature, total suspended solids, total dissolved solids and $\mathrm{pH}(\mathrm{r}=0.87,0.93,0.90$ and 0.85 ; $\mathrm{p}<0.05$ ) respectively.

Total and faecal coli forms bacterial counts helped very much in dividing the lake according to its polluted conditions. With the reference to World Health Organization Standards [25], El- Bashtier area is considered as highly polluted sites in Manzala Lake. It seems that these groups of bacteria are still a powerful tool and the most trusted indicators of water pollution as they are routinely used by many researchers [26]. Also, this area comes first being greatly polluted with numerous health hazardous bacterial counts, such as Vibrio spp., Aeromonas spp. and Staphylococcus according to World Health Organization, WHO [25].

The statistical analysis showed that there is a strong positive correlation between total coli form, faecal coli form bacteria and certain pathogens such as Vibrio spp. On one hand and total dissolved solids in water of the lake on the other in both sites. This could be an indication due to the high load of wastes which are disposed off into the lake water and the marine water and this could exert an adverse effect on these bacteria but along many years they could be genetically changed due the new stressed environment.

Also analysis revealed a positive correlation between Aeromonas spp. and ammonia content. Aeromonas spp. could flourish in the anoxic and polluted water, a phenomenon that suggest the use of Aeromonas as an indicator of pollution. The positive correlation between counts of some pathogens such as Vibrio spp., Staphylococcus and coli forms (total or faecal coli forms) support the idea of suing these pathogens as pollution indicators together with coli forms bacteria.

A similar result was proved by Elshemy [27] who stated that The water quality status of Lake Manzala has been assessed using two different water quality indices (L-WQI and NSF-WQI), based on collected water quality data at 15 stations in the lake and in the main drains. Based on the results, it can be concluded that the water quality status has a critical situation, according to L-WQI, and a very bad situation, in particular, at the southern and the eastern zones. So, an urgent water quality management for the main drains, in particular Bahr Elbaqar drain, should be implemented.

\section{Summary}

Lake Manzala is a brackish lake in northeastern Egypt on the Nile Delta. It is the largest of the northern deltaic lakes of Egypt. The Lake is exposed to high inputs of pollutants from industrial, domestic, and agricultural sources. Climate gases and large amounts of particulate matter, nutrients, bacteria, heavy metals, and toxic organics are transported to the Lake through the wastewater discharge receiving an annual 7.2 billion cubic meters of annual water inflow; 3.9 per cent of which from sewage, 96 per cent from agricultural drainage and 0.1 per cent from industrial drainage. The original capacity of the lake is 0.43 billion cubic meters that is means that Lake Manzala receives 16 times its original size in drainage water inflow. Domestic and industrial wastewaters are transported to Lake Manzala by the Bahr El Baqar drain over a distance of $170 \mathrm{~km}$. The drain is heavily polluted and anoxic over its entire length. The agricultural drainage water containing pesticides and fertilizers and effluents of industrial activities and runoffs in addition to sewage effluents supply the water bodies and sediment with huge quantities of inorganic anions and heavy metals.

Results proved that the southern sector of the lake is strongly damaged from wastewater discharge into the Lake. The physicochemical damages include: Temperature (13.5$\left.32^{\circ} \mathrm{C}\right)$, pH (9.2), Dissolved oxygen $\left(2.5 \mathrm{mgl}^{-1}\right)$, Total dissolved solids (43406 $\left.\mathrm{mgl}^{-1}\right)$, Total suspended solids (387 $\left.\mathrm{mgl}^{-1}\right)$, Ammonia $\left(32.3 \mathrm{mgl}^{-1}\right)$, Nitrite $\left(0.076 \mathrm{mgl}^{-1}\right)$, Nitrate $\left(7.88 \mathrm{mgl}^{-1}\right)$, Phosphate $\left(2.37 \mathrm{mgl}^{-1}\right)$. Cyanide pollution was higher than permissible limit reporting $0.29 \mathrm{mgl}^{-1}$ in the southern sector of the lake. Also, the great density of total viable bacterial count and indicator organisms including total Coli forms, fecal coli forms, Aeromonas spp., Staphylococcus spp. and Vibrio spp. indicate that water in Lake Manzala is highly damaged.

\section{Conclusions}

This study was conducted to evaluate environmental damage caused by wastewater discharge into the lake manzala, Egypt. Water samples were collected from two different sites, Al-Gamil and El-Bashiter areas which represent the northern sector and southern sector of the lake respectively. Results, in comparison with the Egypt legislation national law 48/1982 limits showed thatdissolved oxygen recordedvalues less than the minimum permissible limit while total dissolved solids, total suspended solids, Ammonia, Nitrite, Phosphate and Cyanide recodedvalues higher than permissible limits of the Egypt law. A great density of total viable bacterial count and pollutant indicator organisms such as total Coli forms, fecal coli forms, Aeromonas spp., Staphylococcus spp. and Vibrio sppwas also reported in the lake.

We recommended that Lake Manzala should be divided into two sectors, the northern sector which can be allocated for fishing and the southern sector which should be taken in much governmental interest. The phenomena need more attention in order to reduce the pollution load that reaches the Mediterranean Sea. 


\section{References}

[1] El-Bayomy J (1994). Lake Manzala Area "Geomorphological Study". Faculty of Arts, Cairo University, Egypt, Cairo.

[2] Abdel-Baky, T. E.; Hagras, A. E.; Hassan, S. H. and Zyadah, M. A (1998). Environmental impact assessment of pollution in Lake Manzalah, 1-Distribution of some heavy metals in water and sediment. J. Egypt. Ger. Soc. Zool., 26 (B): 25-38.

[3] El-Ghazali, A. M., Amer, A. A., Mustafa, M. M. (2015). Proposed Decision Support System for Reduction of Total Phosphorus in Lake Manzala. Egyptian Computer Science Journal Vol. 39 No. 4, 56-70.

[4] Santos, I. R., E. V. Silva-Filho, C. E. Schaefer, M. R. Albuquerque- Filho and L. S. Campos (2005). Heavy metals contamination in coastal sediments and soils near the Brazilian Antarctic Station, King George Island. Mar. Poll. Bull., 50: 85-194.

[5] Prasanna, M. V., R. Nagarajan and S. Chidambaram (2012). Assessment of metals distribution and microbial contamination at selected Lake waters in and around Miri city, East Malaysia. Bull Environ Contam Toxicol. 89: 507-51.

[6] ECDG., European Commission DG ENV. E3 Project ENV. E.3/ETU/0058 (2002). Heavy metals in waste. Final report.

[7] Mason, C. F. (2002). Biology of freshwater pollution. 4rd ed. Essex Univ. England. 387pp.

[8] Hasan, E. A. G. (2008). Prediction of Salt Load Flowing to Lake El Manzala Using Artificial Neural Networks. The $3^{\text {rd }}$ International Conference on Water Resources and Arid Environments. 1st Arab Water Forum.

[9] Abd El-Monsef Ahmed El-Badry and Moataz M. Khalifa, (2017). Geochemical Assessment of Pollution at Manzala Lake, Egypt: Special Mention to Environmental and Health Effects of Arsenic, Selenium, Tin and Antimony. Journal of Applied Sciences, 17: 72-80.

[10] McLennan, S. M. and S. R. Taylor (1999). Earth's Continental Crust. In: Encyclopedia of Geochemistry, Marshall, C. P. and R. W. Fairbridge (Eds.). Kluwer Academic Publishers, Dordrecht, Netherlands, pp: 145-151.

[11] Geldreich, E. E. (1978). Bacterial populations and indicator concepts in feces, sewage, storm water and solid wastes. In Indicators of Viruses in Water and Food (ed. G. Berg), pp. 5197, Ann Arbor Science, Ann Arbor, MI.

[12] APHA, American Public Health Association (2012). APHA, AWWA, WEF. Standard Methods for examination of water and wastewater, 22nd ed. Washington.

[13] Fowler, J. and Cohen, L. (1996). Practical statistics for field biology. John Wiley and Sons, New York, USA.
[14] Fathi, A. A. and Abdelzahar, H. M. A. (2003). Limnological studies on the wetland Lake El-Manzala, Egypt, Bull. Fac. Sci. Assiut. Univ., 32(2-D): 215-233.

[15] Ahmed, M. A.; Aly, A. I. M. and Hussien, R. A. (2013). Human-induced and eutrophication impacts on physiochemical and isotopic water characteristics of a northeastern Nile Delta Lake, Egypt. Arab Journal of Nuclear Science and Applications, 46(1): (1-17).

[16] Romairo, R. P.; Boyd, C. E. and Collins, W. J. (1978). Predecting nighttime dissolved oxygen decline in ponds used for Tilapia culture. Trans. m. Fish. Soc., 107: 804-808.

[17] Bruner, G, Jimenez, L.; Mendoza, Y.; Chial, B. and de Chial M. (2013). Bacterial Diversity and Physicochemical Stratification of the Water Column during the Rainy Season in Las Cumbres Lake, Panama. The Internet Journal of Microbiology, 12 (1).

[18] Europa, EU. (2009). Water protection and management Europa. EU legislation, data sheets for surface water quality standards.

[19] El-Gawady, M. (2002). Study on microbial pollution types in Manzala Lake. M. Sc. Thesis, Fac. Agri. Mans. Univ.

[20] Shakweer, L. (2005). Ecological and fisheries development of Lake Manzala (Egypt). 1- Hydrography and chemistry of Lake Manzala. Bull. Nat. Inst. Oceanogr. \& Fish. 31(1): (251-270).

[21] Ramadan, A. A. (2003): Heavy metal pollution and biomonitoring plants in Lake Manzala, Egypt. Pak. J. Biol. Sci. 6(13): 1108-1117.

[22] Berg, H.; Kiibus, M. and Kautsky, N. (1995). Heavy Metals in Tropical Lake Kariba, Zimbabwe. Wat., Air, \& Soil Poll., 83 (3/4): 237-252.

[23] Saeed. S. M. And. Shaker I. M. (2008). Assessment of heavy metals pollution in water and sediments and their effect on oreochromis niloticus in the northern delta lakes, Egypt. The 8th International Symposium on Tilapia in Aquaculture 2008, Egypt.

[24] Agu, C. C.; Menkiti, M. C.; Okolo, B. I. and. Nnaji, P. C. (2014). Evaluation of the level and impact of selected physiochemical parameters of fertilizer effluent on Obinna River, Adani, Enugu State, Nigeria. Journal of Water Resource and Protection, 6, 722-730.

[25] World Health Organization, WHO (1989). Health guidelines for the use of waste water in agriculture and aquaculture. Vol. 2 , Switzerland.

[26] Simpson, J. M., Santo, J. W. and Reasoner, D. J. (2002). Microbial source tracking: State of Science. Environ. Sci. Technolo. 36(24): 5279-5288.

[27] Elshemy, M. (2016). Water Quality Assessment of Lake Manzala, Egypt: A Comparative Study. International Journal of Scientific Research in Environmental Sciences, 4(6), 01960207. 